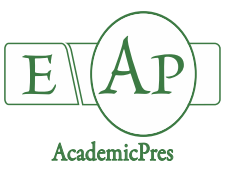

Fortis Hernandez M et al. (2021)

Notulae Botanicae Horti Agrobotanici Cluj-Napoca

Volume 49, Issue 1, Article number 11999

DOI: $10.15835 /$ nbha49111999

Research Article

\title{
Effect of substrates formulated with organic materials on yielding, commercial and phytochemical quality, and benefit-cost ratio of tomato (Solanum lycopersicum L.) produced under greenhouse conditions
}

\author{
Manuel FORTIS-HERNÁNDEZ ${ }^{1}$, Eliever ANTONIO-ORDONEEZ², \\ Pablo PRECIADO-RANGEL ${ }^{1}$, Miguel Á. GALLEGOS-ROBLES ${ }^{3}$, \\ Cirilo VÁZQUEZ-VÁZQUEZ ${ }^{3}$, Arturo REYES-GONZALES ${ }^{4}$, \\ Juan R. ESPARZA-RIVERA ${ }^{5 *}$
}

\begin{abstract}
${ }^{1}$ Tecnológico Nacional de México - Campus Instituto Tecnológico de Torreón, Carretera Torreón-San Pedro Km 7.5, Ejido Ana Torreón,Coahuila27170,México; fortismanuel@hotmail.com;ppreciador@yahoo.com.mx

${ }_{2}^{2}$ Maestría en Ciencias en Suelos, Tecnológico Nacional de México - Campus Instituto Tecnológico de Torreón, Carretera TorreónSan Pedro Km 7.5, Ejido Anna Torreón, Coahuila 27170, México; textrc2010@live.com

${ }^{3}$ Universidad Juárez del Estado de Durango, Facultad de Agricultura y Zootecnia, Ejido Venecia, Carretera Tlahualilo km 35, Gómez Palacio,Durango 35111, México; garoma64@hotmail.com; cirvaz60@hotmail.com

${ }^{4}$ Instituto Nacional de Investigaciones Forestales, Agrícolas y Pecuarias (INIFAP), Blvd. José Santos Valdez No. 1200 Pte. Matamoros,Coahuila27440,México; reyes.arturo@inifap.gob.mx

${ }^{5}$ Universidad Juárez del Estado de Durango, Facultad de Ciencias Químicas unidad Gómez Palacio, Avenida Artículo 123 S/N,

Fraccionamiento Filadelfia, Gómez Palacio,Durango 35010, México; jresparza02001@yahoo.com ("${ }^{*}$ orresponding author)
\end{abstract}

\section{Abstract}

The objective of this study was to evaluate the effect of substrates formulated with different blends of sand-solarized manure and sand-vermicompost over yield, commercial and phytochemical quality of greenhouse tomatoes, and in addition to determine their benefit-cost $(\mathrm{B} / \mathrm{C})$ ratio for organic production of tomato. Six substrates were established consisting in blends of sand with 20,30 or $40 \%$ of solarized manure (SM20, SM30 and SM40), and 20, 30 and 40\% of vermicompost (VC20, VC30 and VC40), and control (TA) of sand fertilized with Steiner solution. Fruit yielding, commercial (fruit size, equatorial and longitudinal diameter, firmness, and soluble solids content), and nutraceutical quality (phenolic and lycopene content) were evaluated. In addition, cost-benefit $(\mathrm{B} / \mathrm{C})$ ratio of treatments was compared. Micro morphological analysis of the organic materials showed microscopic differences that could affect substrate functional properties. Substrate type affect yielding, and VC40 substrate had a higher yield than SM substrates, but SM20 had the highest phenolic and lycopene content in fruit, in addition to the highest cost-benefit production ratio (2.31). These results confirm that substrates formulated with blends of sand and either SM or VC can be used for organic production of tomato fruits with an adequate commercial and phytochemical quality without affecting yield, additionally to the economic advantages of such substrates for protected agriculture systems.

Keywords: lycopene; organic production; phenolics; tomato; vermicompost

Received: 17 Jul 2020. Received in revised form: 15 Jan 2021. Accepted: 25 Jan 2021. Published online: 27 Jan 2021.

From Volume 49, Issue 1, 2021, Notulae Botanicae Horti Agrobotanici Cluj-Napoca journal will use article numbers in place of the traditional method of continuous pagination through the volume. The journal will continue to appear quarterly, as before, with four annual numbers. 


\section{Introduction}

Nowadays, consumers prefer fresh food products with a high nutritive quality as well as chemical-free (Wang and $\mathrm{Wu}, 2010$ ). An alternative that meets such requirements is organic vegetable products obtained under protected agriculture systems, like either in greenhouses or in shade-net houses (Miles and Peet, 2002). In organic production is used either organic materials or organic and mineral components blends as substrates under greenhouse and shade house conditions. The use of these materials has advantages over traditional soil farming since the physical and chemical characteristics of the substrate can be manipulated in order to improve crop yield and quality (Burnett et al., 2016). A substrate should have important characteristics such a high porosity, low saline content, good mechanical properties, and a low cost; in addition, that it must provide an adequate mechanical support or anchorage to plants, serve as a nutrient and water reservoir, and facilitate oxygen diffusion to roots as well as a good gas interchange (Yeager et al., 2007; Suvo et al., 2017). However, it is not clearly defined what an organic substrate is, since a soil is considered as organic when it presents organic materials whose organic carbon content is higher than that described for mineral soil materials, as established in the Keys to Soil Taxonomy (USDA, 2014); nevertheless, there is not a delimited classification criterion for an organic substrate. On the other side, one of the highest costs in greenhouse crop production is indeed the substrate, whose price depends on the substrate type as well as the materials used for its formulation (Cruz et al., 2013). Regarding this, sand is a low-cost, easily acquired mineral material that could be used as a vegetable production substrate, but it has an important disadvantage, which is its low water retention capacity; thereby sand must be mixed with either mineral (Segura-Castruita et al., 2008) or organic materials (Atiyeh et al., 2000; Burnett et al., 2016) in order to improve its physical-chemical characteristics. Two low-cost organic materials that can be used to formulate substrates for vegetable production under protected agriculture systems are solarized manure and vermicompost obtained from cattle manure (Fortis et al., 2012; Tringovska and Dintcheva, 2012). Solarized manure is an organic material that gradually releases easily available nutrients for plants (Vázquez et al., 2011). Vermicompost contains humic substances that act as growth regulators (Domínguez et al., 2010), elevates cationic exchange capacity, and increases moisture retention capacity (Hashemimajd et al., 2004). Hence, organic these materials could be used to formulate organic substrates for producing horticultural produce with a high nutritional and commercial quality, including tomato (Solanum lycopersicum L.), which is one of the most important vegetable produce worlds widely.

Tomato fruit contains mineral salts, vitamins $\mathrm{A}$ and $\mathrm{C}$, and phytochemicals such as lycopene and phenolic compounds. Consumption of foods with these phytochemicals has been associated with prevention of chronic diseases and cardiovascular problems (Knekt et al., 2002; Raffo et al., 2006). Phenolic compounds and lycopene content depend on the tomato variety or type, environmental temperature, illumination, and water and nutrition supply (Dumas et al., 2003), but also increase in tomato fruits as a defence response to some stress types. Thus, phenolics and lycopene content could be regulated in vegetable production systems under protected agriculture, like under greenhouse or shade net conditions, by manipulating substrate formulation. Hence, the mixture of solarized manure or vermicompost with mineral materials such as sand to formulate substrates for tomato production under protected agriculture conditions can contribute to obtain fruits with a high phytochemical content without decreasing yielding and commercial fruit quality, in addition to the increase in benefit/cost ratio compared to the use of traditional substrates under chemical fertilization.

The aims of the current study were to evaluate yielding, commercial and phytochemical fruit quality and economic advantages of tomato fruits produced using organic substrates formulated with vermicompost and/or solarized manure mixed with sand under greenhouse conditions. 


\section{Materials and Methods}

Substrates formulation

The base material for substrate formulation was river sand disinfected using a 5\% sodium hypochlorite solution, washed with tap water, and dried at room temperature for three days (Sánchez et al., 2016). The organic materials used for the substrate formulations were solarized manure (SM), and vermicompost (VC) made from cattle manure in the Instituto Technologico de Torreón (Flores et al., 2015). Manure was obtained from Holstein cattle of a local dairy stable (Torreon, Coahuila, México). Composting process consisted in covering the manure for 70 days with a transparent $30 \mu$-thick plastic without albedo (Vázquez Vázquez et al., 2010). Vermicompost was obtained in a laboratory of the Instituto Tecnológico de Torreón using Eisenia foetida earthworms for digesting the manure for 90 days (Frederickson et al., 2007).

The obtained organic materials (solarized manure $[\mathrm{SM}]$ and vermicompost $[\mathrm{VC}]$ ) were mixed with sanitized sand at three ratios. The VC substrates were composed by sand with 20\% (VC20), 30\% (VC30) and $40 \%$ (VC40) of vermicompost; meanwhile the SM substrates were mixtures of sanitized sand with 20\% (SM20), 30\% (SM30) and 40\% (SM40) of solarized manure. These six treatments were formulated according to previous studies reporting a good performance of these organic materials at such ratios (Moreno et al., 2012). A control substrate of sanitized sand (TA) was included.

\section{Plant material}

The plant material used was tomato (Solanum lycopersicum L. esculentum) cv. 'Sahel' (Syngenta ), a Saladette type, since it is a variety with a short growth cycle, and it is mostly destined for fresh consumption. The study was conducted in a greenhouse at the Instituto Tecnológico de Torreón (ITT), located in Torreón, Coahuila (Mexico) between the coordinates $24^{\circ} 30^{\prime}$ and $27^{\circ} \mathrm{N}, 102^{\circ} 00^{\prime}$ and $104^{\circ} 40^{\prime} \mathrm{W}$, at $1120 \mathrm{~m}$ above sea level. The greenhouse was a Mini-Green type with vertical columns and a surface of $120 \mathrm{~m}^{2}$ covered with UV resistant polyethylene caliber 720 (30\% diffuse shade). The greenhouse has controlled ventilation, and its windows have crystalline $25 \times 25$ threads/inch anti-aphid screens for protection against pests and insects. Greenhouse conditions throughout the production season were $70-75 \%$ of humidity content, and a room temperature within $22-32{ }^{\circ} \mathrm{C}$.

Tomato seedlings were transplanted after thirty-five days from germination to 600 caliber black polyethylene bags with a capacity of $15 \mathrm{~kg}$ (one plant per bag). The six treatments containing organic materials were irrigated with tap water (Moreno et al., 2012), while the TA was irrigated and fertilized daily with a Steiner nutrient solution (Steiner, 1984), which was prepared using inorganic salts reagent grade and distilled water, obtaining the following nutrient concentrations (in $\mathrm{mg} / \mathrm{L}$ ): nitrogen (168), phosphorus (31), potassium (273), calcium (80), magnesium (48), iron (2), manganese (0.7), copper (0.02), zinc (0.09), boron (0.5), and molybdenum (0.04). Applied volume of water and Steiner solution was modified depending on the crop development stage: $0.5 \mathrm{~L}$ per plant daily during growth and up to $1.5 \mathrm{~L}$ during development and harvest [10]. There were seven treatments (six organic substrate treatments plus control) in a completely randomized experimental design, and four treatment replicates were run.

\section{Analytical tests for organic materials used for substrates formulation}

The analytical tests run for the sanitized sand, solarized manure and vermicompost were: organic matter content (by calcination), $\mathrm{pH}$, electric conductivity of a 1:5 (v:v) extract, nitrate content (by micro Kjeldahl), and bulk density. Besides, determination of elemental composition and a micro morphological analysis of the solarized manure and vermicompost were run. The micro morphological analyses were performed using an electronic scanning microscope (JMS-6480LV, JEOL, Celaya, Guanajuato, México) coupled with an X ray dispersive probe (INCAx-sight Oxford Instruments). 


\section{Analytical tests for organic substrates}

The physical and chemical variables evaluated in the six formulated substrates were: organic matter content (by calcination), $\mathrm{pH}$, electric conductivity of a 1:5 (v:v) extract, nitrate content (by micro Kjeldahl), and bulk density.

\section{Evaluation of tomato yield and commercial fruit quality}

The production variable evaluated in tomato plant was fruit yielding ( $\mathrm{kg}$ of tomato fruit/plant), meanwhile for commercial fruit quality was evaluated polar and equatorial diameters; pericarp thickness (using a Vernier); firmness, measured with a penetrometer Extech FHT200 (Extech Instruments Corporation, Nashua, NH, USA); and total soluble solids (TSS), measured with a manual refractometer Sper Scientific 30000 (Sper Scientific Ltd, Scottsdale, AZ, USA).

\section{Nutraceutical quality of tomato fruit}

In regard of nutraceutical quality of tomato fruits were evaluated the total phenolic and lycopene content. Total phenolic content was determined using the Folin-Ciocalteau method (Singleton et al., 1999). A calibration curve was prepared using gallic acid as standard, having a good linearity $\left(\mathrm{r}^{2}>0.999\right)$. The results were reported in $\mathrm{mg}$ of gallic acid equivalent (mg GAE) per $100 \mathrm{~g}$ fresh weight. Lycopene content was determined following the protocol of Mayeaux et al. (2006) for obtaining the lycopene extract. Lycopene quantification was done using an adaptation of the method published by Anguelova and Warthersen (2000), using a high precision liquid chromatograph Agilent 2100 Series equipped with a Supelco Discovery ${ }^{\circ} \mathrm{C} 18$ column $(5 \mathrm{~cm} \times 4.6 \mathrm{~mm} \times 5 \mu \mathrm{m})$, having a flow of $0.5 \mathrm{~mL} / \mathrm{min}$, and monitoring the eluent at $472 \mathrm{~nm}$ in a diode array detector. The liquid chromatograph used the Chem-Station software for LC/MSD (Agilent Technologies, Palo Alto, Calif., USA), and a lycopene (Sigma-Aldrich) calibration curve with a good linearity $(\mathrm{r} 2>0.999)$ was prepared. The results were reported in $\mu \mathrm{g}$ of lycopene/g tomato solids.

\section{Benefit/cost ratio of tomato production}

An economic analysis (per square meter) was conducted, following the methodology of Perrin et al. (1976), using only variable costs since fixed costs are considered amortized. Input features (sand and organic materials, nutritive solution, black plastic bags, labor, organic herbicides, etc.) that make up the variable costs are shown in Table 1. Gross average yielding per square meter of each treatment was multiplied by the corresponding price of one tomato fruit $\mathrm{kg}$ ( $\$ 0.85$ American dollars for tomatoes produced using nutrient solution, and \$1.19 American dollars for tomatoes produced with organic materials).

Table 1. Variable costs for greenhouse Saladette tomato production using sand-vermicompost, sandsolarized manure, and sand substrates

\begin{tabular}{|c|c|c|c|}
\hline Material & \multicolumn{2}{|c|}{ Unit } & Unitary Price $(\$)$ \\
\hline Sand & $\mathrm{kg}$ & 1 & 0.013 \\
\hline Vermicompost & $\mathrm{kg}$ & 1 & 0.17 \\
\hline Solarized manure & $\mathrm{kg}$ & 1 & 0.60 \\
\hline Nutritious solution (90 days) & $\mathrm{L} / \mathrm{m}^{2}$ & 210 & 1.80 \\
\hline Flower pot & piece & 1 & 0.13 \\
\hline
\end{tabular}

Abbreviations or symbols: \$, American dollar;

The obtained result was the raw profit for the producer. The economic efficiency of the treatments was evaluated by a benefit/cost ratio $(\mathrm{B} / \mathrm{C})$ that includes production value (gross profit) per square meter, and use and management costs of the substrates (expenditures) on the same area, using the equation [a]:

$$
\mathrm{B} / \mathrm{C}=\frac{\mathrm{bb}-\mathrm{cp}}{\mathrm{cp}} \quad[\mathrm{a}]
$$


B/C stands for the benefit/cost ratio; bb: gross benefit; cp: production cost (all costs were calculated in American dollars); where the highest $\mathrm{B} / \mathrm{C}$ ratio was the best treatment determined from an economic perspective; meaning that updated benefits were higher than updated costs (Izquierdo et al., 1992).

\section{Statistical analysis}

The results of the studied variables were subjected to an analysis of variance to detect significant effects of treatments $(\mathrm{p}<0.05)$, and treatment means were compared with a Tukey test $(\mathrm{p}<0.05)$, using the Statistical Analysis System (SAS) version 9.1 statistical software (SAS, 2009).

\section{Results}

\section{Physical and chemical characteristics of the organic materials used for substrate formulation}

Solarized manure (SM) and vermicompost (VC) had different chemical characteristics; including $\mathrm{pH}$, and organic matter, potassium and nitrate content $(\mathrm{p}<0.05$, Table 2$)$. Solarized manure $\mathrm{pH}$ was neutral $(7.1)$, while vermicompost $\mathrm{pH}$ was slightly alkaline (7.9), while SM was higher than VC regarding organic matter $(25.0 \%)$ and potassium content $(15.1 \%, \mathrm{p}<0.05)$. However, vermicompost had a higher NO3 concentration content $(48.3 \%, \mathrm{p}<0.05)$ than solarized manure. The remaining chemical characteristics were similar in both organic materials $(\mathrm{p}>0.05)$.

Table 2. Physical and chemical properties of organic materials used for substrate formulations

\begin{tabular}{|c|c|c|c|c|c|c|c|c|}
\hline $\begin{array}{c}\text { Organic } \\
\text { materials }\end{array}$ & $\begin{array}{c}\mathrm{Bd} \\
\left(\mathrm{g} / \mathrm{cm}^{3}\right)\end{array}$ & $\begin{array}{c}\mathrm{EC} \\
(\mathrm{dS} / \mathrm{m})\end{array}$ & $\begin{array}{c}\mathrm{OM} \\
(\mathrm{g} / \mathrm{kg})\end{array}$ & $\begin{array}{c}\mathrm{CEC} \\
(\mathrm{cmol} / \mathrm{kg})\end{array}$ & PES $(\%)$ & $\begin{array}{c}\mathrm{NO}_{3-} \\
(\mathrm{mg} / \mathrm{kg})\end{array}$ & $\begin{array}{c}\mathrm{P} \\
(\mathrm{mg} / \mathrm{kg})\end{array}$ & $\begin{array}{c}\mathrm{K}^{+} \\
(\mathrm{mg} / \mathrm{kg})\end{array}$ \\
\hline $\mathrm{VC}^{*}$ & $0.75 \mathrm{a}$ & $3.2 \mathrm{a}$ & $334.5 \mathrm{~b}$ & $95.3 \mathrm{a}$ & $2.99 \mathrm{a}$ & $13.73 \mathrm{a}$ & $15.34 \mathrm{a}$ & $164.71 \mathrm{~b}$ \\
\hline $\mathrm{SM}^{* *}$ & $0.90 \mathrm{a}$ & $3.3 \mathrm{a}$ & $418.1 \mathrm{a}$ & $77.6 \mathrm{a}$ & $2.76 \mathrm{a}$ & $9.26 \mathrm{~b}$ & $16.54 \mathrm{a}$ & $189.63 \mathrm{a}$ \\
\hline
\end{tabular}

Means followed by different letter in columns are significantly different, according to the t-test $(\mathrm{p}<0.05)$. Abbreviations or symbols: *VC, vermicompost; SM, solarized manure, EC, electric conductivity; OM, organic matter; CEC, cation exchange capacity; PES, percent exchangeable sodium.

Micro morphological characteristics of these two organic materials can contribute to the formulated substrate properties (Figure 1). Solarized manure consisted of isolated particles, whose size varied from $<2.0$ $\mu \mathrm{m}$, like in clay granules that do not form aggregates, to $50-2000 \mu \mathrm{m}$ in sand particles and woody and tissue parts (Figures $1 \mathrm{a}$ and $1 \mathrm{~b})$. On the other hand, vermicompost contains small aggregates $(2-50 \mu \mathrm{m})$ somewhat crumbly and brittle, formed with mineral and organic particles of different size like silt and clay blended into a fine matrix (Figures $1 \mathrm{c}$ and $1 \mathrm{~d}$ ).

The organic materials had different elemental composition ( $\mathrm{p}<0.05$, Table 3$)$, since $\mathrm{VC}$ had a higher content of nitrogen, oxygen, sodium, magnesium, aluminium, silicon, phosphorous, calcium and iron; meanwhile solarized manure contains more carbon, chloride and potassium than vermicompost.

\section{Physical and chemical properties of the organic substrates}

The substrates formulated with organic materials were different in $\mathrm{pH}$ and organic matter (OM) content ( $\mathrm{p}<0.05$, Table 4$)$, having $\mathrm{pH}$ values of $7.65-8.21$, and organic material content of $35.00-114.03 \mathrm{~g} / \mathrm{kg}$. Regarding organic matter SM substrates had a higher OM content than VC substrates; however bulk density and electric conductivity were similar in all six formulated substrates except VC40 substrate, with an EC of $1.06(\mathrm{p}<0.05)$. 
Fortis Hernandez M et al. (2021). Not Bot Horti Agrobo 49(1):11999

Table 3. Elemental composition of organic materials used for substrate formulation

\begin{tabular}{|c|c|c|}
\hline Chemical element & Solarized manure & Vermicompost \\
\hline Carbon & $39.86 \mathrm{a}$ & $18.47 \mathrm{~b}$ \\
\hline Nitrogen & $1.97 \mathrm{~b}$ & $2.24 \mathrm{a}$ \\
\hline Oxygen & $39.83 \mathrm{~b}$ & $45.91 \mathrm{a}$ \\
\hline Sodium & $0.56 \mathrm{~b}$ & $0.83 \mathrm{a}$ \\
\hline Magnesium & $0.50 \mathrm{~b}$ & $1.24 \mathrm{a}$ \\
\hline Aluminium & $1.25 \mathrm{~b}$ & $3.15 \mathrm{a}$ \\
\hline Silicon & $7.81 \mathrm{~b}$ & $15.62 \mathrm{a}$ \\
\hline Phosphorus & $0.25 \mathrm{~b}$ & $0.79 \mathrm{a}$ \\
\hline Sulphur & $0.62 \mathrm{a}$ & $0.53 \mathrm{a}$ \\
\hline Chlorine & $1.13 \mathrm{a}$ & $0.29 \mathrm{~b}$ \\
\hline Potassium & $5.12 \mathrm{a}$ & $3.46 \mathrm{~b}$ \\
\hline Calcium & $2.17 \mathrm{~b}$ & $7.75 \mathrm{a}$ \\
\hline Iron & $0.52 \mathrm{~b}$ & $1.76 \mathrm{a}$ \\
\hline
\end{tabular}

Results in \% dry weight basis. Values in rows followed by different letters are significantly different, according to the $\mathrm{t}-$ test $(\mathrm{p}<0.05)$.
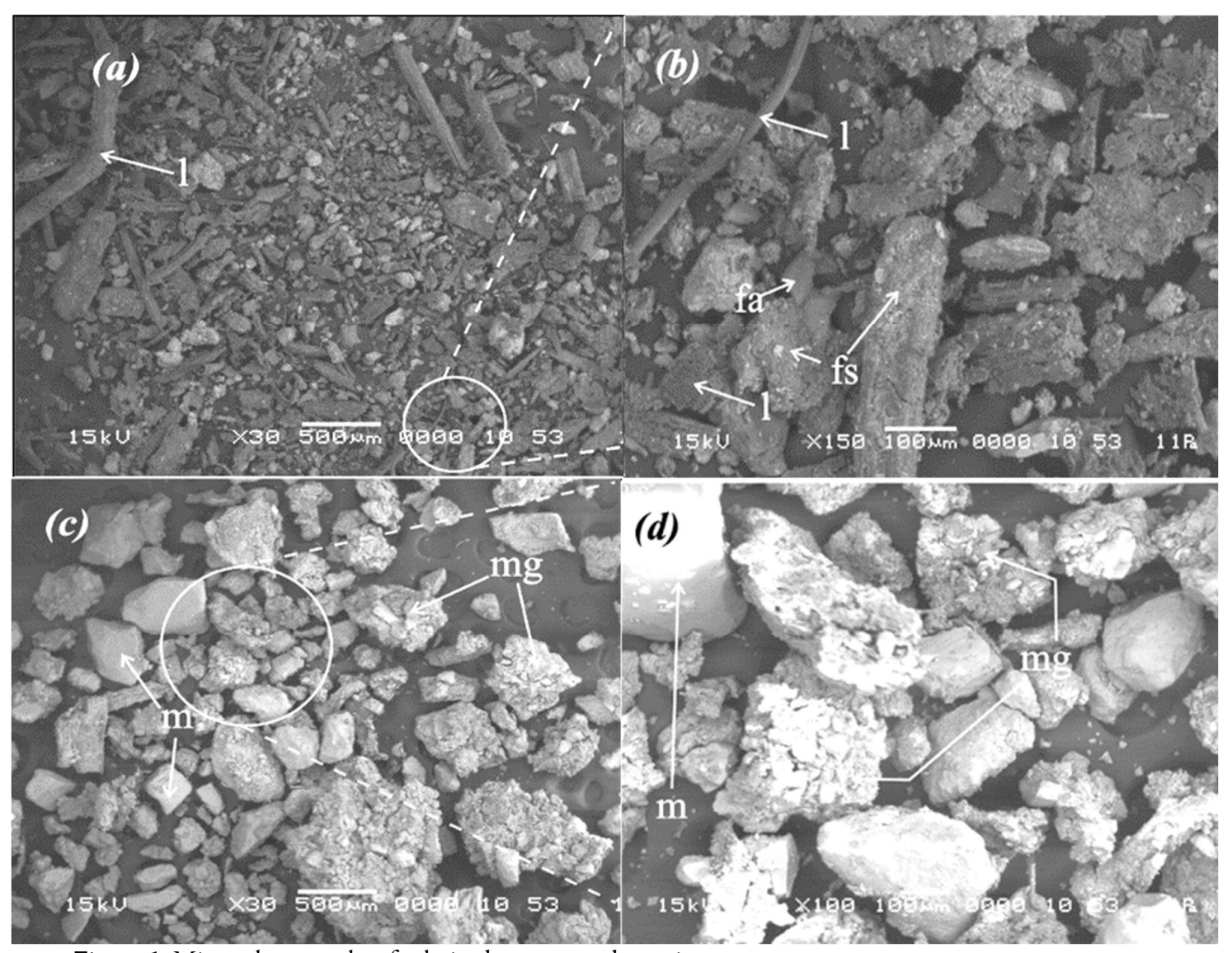

Figure 1. Micro photographs of solarized manure and vermicompost

(a) Solarized manure at 30X $(1: 500 \mu \mathrm{m})$; (b) Solarized manure at 150X $(1: 100 \mu \mathrm{m})$; Vermicompost at 30X (1:500 $\mu \mathrm{m})$; (d) Vermicompost at 100X $(1: 100 \mu \mathrm{m})$. Abbreviations: $\mathrm{fa}=$ angular blocks, $\mathrm{fs}=$ subangular blocks, $\mathrm{l}$ = woody parts, $\mathrm{m}=$ minerals, $\mathrm{mg}=$ crumb structure. 
Table 4. Physical and chemical characteristics of sand and organic substrates used for tomato production under greenhouse conditions

\begin{tabular}{|c|c|c|c|c|}
\hline Organic material & $\mathrm{pH}$ & $\begin{array}{c}\mathrm{EC} \\
(\mathrm{dS} / \mathrm{m} 1)\end{array}$ & $\begin{array}{c}\mathrm{Bd} \\
\left(\mathrm{g} / \mathrm{cm}^{3}\right)\end{array}$ & $\begin{array}{c}\mathrm{OM} \\
(\mathrm{g} / \mathrm{kg}) \\
\end{array}$ \\
\hline Vermicompost (VC) & $7.91 \mathrm{ab}$ & $3.21 \mathrm{a}$ & $0.75 \mathrm{c}$ & $334.45 \mathrm{~b}$ \\
\hline Solarized manure (SM) & $7.01 \mathrm{c}$ & $3.26 \mathrm{a}$ & $0.90 \mathrm{c}$ & $418.10 \mathrm{a}$ \\
\hline \multicolumn{5}{|l|}{ Substrate } \\
\hline TA (Control with chemical fertilization*) & $6.50 \mathrm{c}$ & $2.50 \mathrm{~b}$ & $1.40 \mathrm{a}$ & $0.00 \mathrm{f}$ \\
\hline VC 20 (80\% Sand + 20\% Vermicompost) & $7.92 \mathrm{ab}$ & $0.44 \mathrm{~d}$ & $1.23 \mathrm{ab}$ & $35.00 \mathrm{ef}$ \\
\hline VC 30 (70\% Sand + 30\% Vermicompost) & $7.89 \mathrm{ab}$ & $0.51 \mathrm{~d}$ & $1.16 \mathrm{~b}$ & $56.08 \mathrm{de}$ \\
\hline VC 40 (60\% Sand + 40\% Vermicompost) & $7.65 \mathrm{~b}$ & $1.06 \mathrm{c}$ & $1.08 \mathrm{~b}$ & $79.64 \mathrm{~cd}$ \\
\hline SM 20 (80\% Sand + 20\% Solarized manure $)$ & $8.03 \mathrm{ab}$ & $0.55 \mathrm{~d}$ & $1.25 \mathrm{ab}$ & $51.54 \mathrm{de}$ \\
\hline SM 30 (70\% Sand + 30\% Solarized manure) & $8.06 \mathrm{ab}$ & $0.59 \mathrm{~d}$ & $1.19 \mathrm{~b}$ & $81.12 \mathrm{~cd}$ \\
\hline SM 40 (60\% Sand + 40\% Solarized manure $)$ & $8.21 \mathrm{a}$ & $0.60 \mathrm{~d}$ & $1.13 \mathrm{~b}$ & $114.03 \mathrm{c}$ \\
\hline
\end{tabular}

${ }^{*}$ Chemical fertilization consisted in application of Steiner solution. Means followed by different letters in the same column are significantly different, according to the Tukey test $(\mathrm{p}<0.05)$. Abbreviations or symbols: EC, electric conductivity; Bd, bulk density; OM, organic matter.

\section{Tomato yielding}

Tomato yielding was different among treatments, with TA substrate having the highest yield $(17.20$ $\mathrm{kg} / \mathrm{m}^{2}$, Figure 2), followed by the VC40 substrate $\left(14.72 \mathrm{~kg} / \mathrm{m}^{2}\right)$, meanwhile the SM 20 obtained the lowest yield $\left(11.52 \mathrm{~kg} / \mathrm{m}^{2}\right)$.

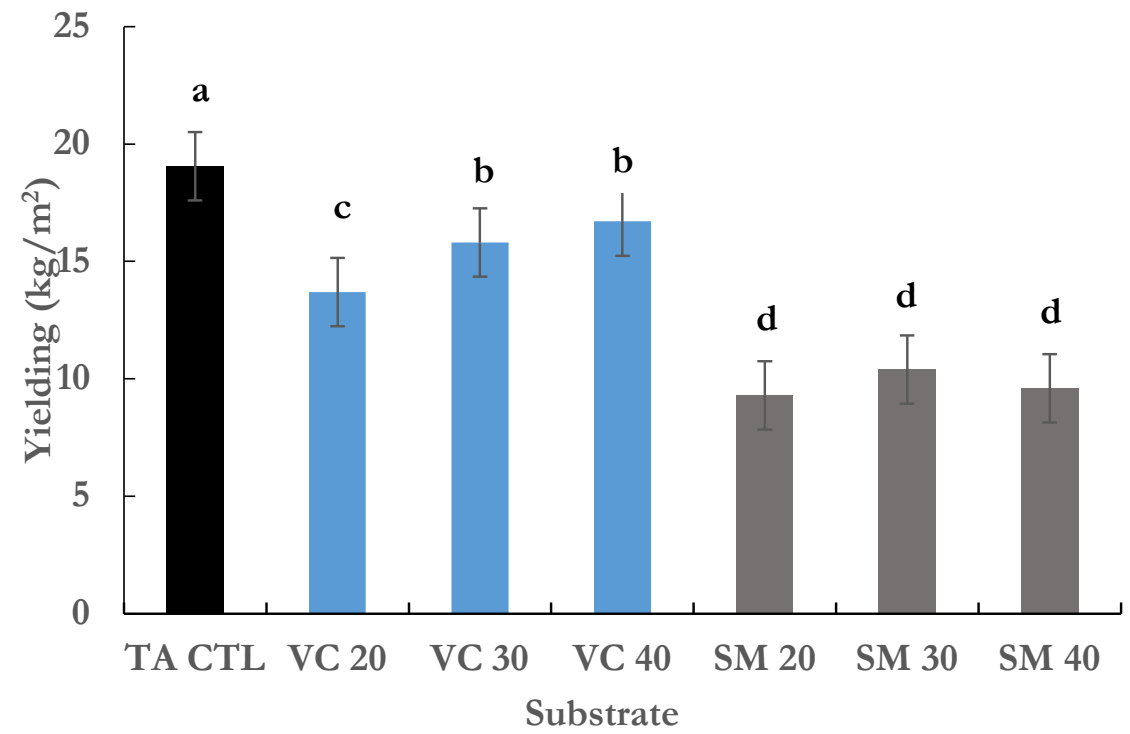

Figure 2. Yielding of Saladette tomato fruit produced in organic substrates formulated with sandvermicompost and sand-solarized manure

Results $(\mathrm{n}=4)$ reported in $\mathrm{kg} / \mathrm{m}^{2}$. TA: Control with chemical fertilization; VC 20: 80\% Sand + 20\% Vermicompost; VC 30: 70\% Sand + 30\% Vermicompost; VC 40: 60\% Sand + 40\% Vermicompost; SM 20: 80\% Sand + 20\% Solarized manure; SM 20: 80\% Sand + 20\% Solarized manure; SM 20: 80\% Sand + 20\% Solarized manure. Bars with a different letter are significantly statistical different, according to the Tukey test $(\mathrm{p}<0.05)$. 


\section{Commercial quality of tomato fruit}

The tomato fruit quality parameters were different among all treatments $(\mathrm{p}<0.05)$, except in polar diameter (Table 5). Tomato fruits produced in the control substrate (fertilized chemically) had the highest values of equatorial diameter, pericarp thickness, texture firmness and soluble solids content followed by VC substrates and SM substrates $(\mathrm{p}<0.05)$. Nevertheless, tomato fruits of all treatment substrates had firmness values above $6.00 \mathrm{~N}$ (Figure 3), which could be considered as a firm texture in this produce; in addition to that tomato fruits produced in $\mathrm{VC}$ treatments had adequate soluble solids content for tomato processing (Figure 4).

Table 5. Results* of the quality variables of Saladette tomato fruit produced in organic substrates formulated with sand-vermicompost and sand-solarized manure

\begin{tabular}{|c|c|c|c|}
\hline Treatment substrate & $\begin{array}{c}\text { Polar } \\
\text { diameter }\end{array}$ & $\begin{array}{c}\text { Equatorial } \\
\text { diameter }\end{array}$ & $\begin{array}{c}\text { Pericarp } \\
\text { thickness }\end{array}$ \\
\hline TA (Control with chemical fertilization**) & $63.6 \mathrm{a}$ & $51.8 \mathrm{a}$ & $9.1 \mathrm{a}$ \\
\hline VC 20 (80\% Sand + 20\% Vermicompost) & $62.5 \mathrm{a}$ & $48.6 \mathrm{a}$ & $8.6 \mathrm{a}$ \\
\hline VC 30 (70\% Sand + 30\% Vermicompost) & $62.4 \mathrm{a}$ & $48.8 \mathrm{a}$ & $7.6 \mathrm{~b}$ \\
\hline VC 40 (60\% Sand + 40\% Vermicompost) & $63.5 \mathrm{a}$ & $48.8 \mathrm{a}$ & $9.7 \mathrm{a}$ \\
\hline SM 20 (80\% Sand + 20\% Solarized manure) & $62.8 \mathrm{a}$ & $45.6 \mathrm{~b}$ & $6.0 \mathrm{c}$ \\
\hline SM 30 (70\% Sand + 30\% Solarized manure) & $62.2 \mathrm{a}$ & $46.9 \mathrm{~b}$ & $6.3 \mathrm{~b}$ \\
\hline SM 40 (60\% Sand + 40\% Solarized manure) & $62.1 \mathrm{a}$ & $43.1 \mathrm{~b}$ & $6.5 \mathrm{~b}$ \\
\hline
\end{tabular}

${ }^{*}$ Result means $(\mathrm{n}=4)$, reported in $\mathrm{mm}$. ${ }^{* *}$ Treatment fertilized with Steiner solution. Values followed by different letters in the same column are significantly different, according to the Tukey test $(\mathrm{p}<0.05)$.

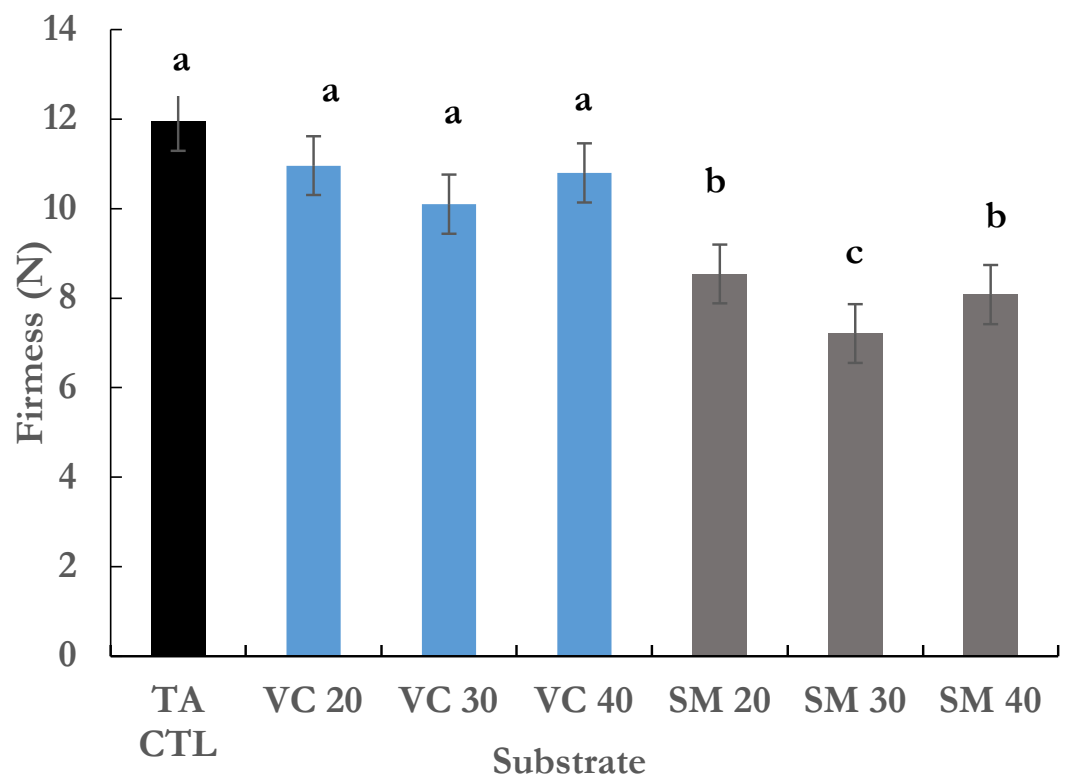

Figure 3. Firmness of tomato of Saladette tomato fruit produced in organic substrates formulated with sand-vermicompost and sand-solarized manure

Results $(\mathrm{n}=4)$ reported in $\mathrm{kg} / \mathrm{m}^{2}$. TA: Control with chemical fertilization; VC 20: 80\% Sand + 20\% Vermicompost; VC 30: 70\% Sand + 30\% Vermicompost; VC 40: 60\% Sand + 40\% Vermicompost; SM 20: 80\% Sand + 20\% Solarized manure; SM 20: $80 \%$ Sand + 20\% Solarized manure; SM 20: 80\% Sand + 20\% Solarized manure. Bars with a different letter are significantly statistical different, according to the Tukey test $(\mathrm{p}<0.05)$. 


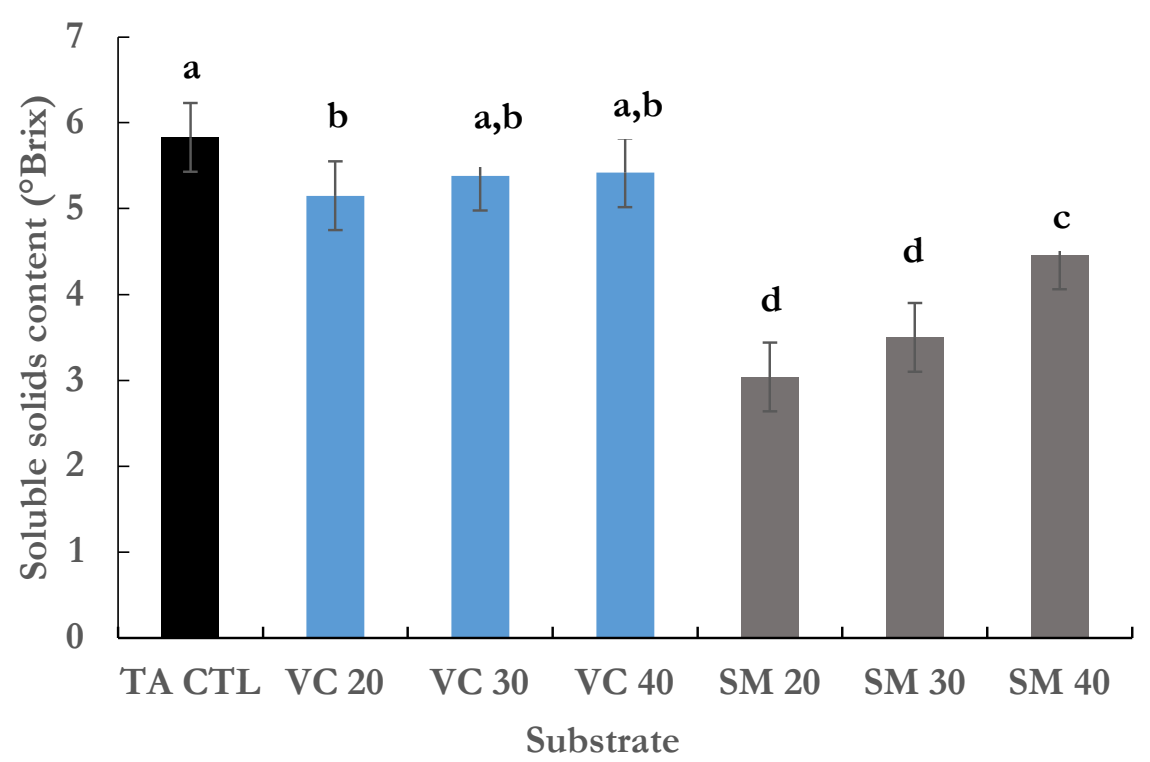

Figure 4. Soluble solids content of Saladette tomato fruit produced in organic substrates formulated with sand-vermicompost and sand-solarized manure

Results $(\mathrm{n}=4)$ reported in ${ }^{\circ}$ Brix. TA: Control with chemical fertilization; VC 20: 80\% Sand + 20\% Vermicompost; VC 30: 70\% Sand + 30\% Vermicompost; VC 40: 60\% Sand + 40\% Vermicompost; SM 20: 80\% Sand + 20\% Solarized manure; SM 20: $80 \%$ Sand + 20\% Solarized manure; SM 20: 80\% Sand + 20\% Solarized manure. Bars with a different letter are significantly statistical different, according to the Tukey test $(\mathrm{p}<0.05)$.

\section{Phytochemical quality of tomato fruit}

Phenolic compound content of tomato fruits was different among the treatments $(\mathrm{p}<0.05)$ within a range of 19.7-28.5 mg GAE/100 $\mathrm{g}$ fresh weight of fruit, having the SM30 the highest value, meanwhile fruits obtained in the VC20 substrate had the lowest phenolic content (Table 6). Lycopene content was within a range of 20.4-33.7 $\mu \mathrm{g}$ of lycopene/g dry weight, and it was affected by the substrate formulation $(\mathrm{p}<0.05$, Table 6), resulting in a decrease of lycopene content as the \% of solarized manure in the substrates increased, whilst the three VC substrates had similar lycopene content.

Table 6. Results* of phenolic and lycopene content of Saladette tomato fruit produced in organic substrates formulated with sand-vermicompost and sand-solarized manure

\begin{tabular}{|c|c|c|}
\hline Treatment substrate & Phenolic content $^{* *}$ & Lycopene content $^{* * *}$ \\
\hline TA (Control with chemical fertilization**) & $27.7 \mathrm{a}$ & $25.0 \mathrm{bc}$ \\
\hline VC 20 (80\% Sand + 20\% Vermicompost) & $19.7 \mathrm{~b}$ & $27.2 \mathrm{~b}$ \\
\hline VC 30 (70\% Sand + 30\% Vermicompost) & $22.5 \mathrm{~b}$ & $24.0 \mathrm{bc}$ \\
\hline VC 40 (60\% Sand + 40\% Vermicompost) & $21.1 \mathrm{~b}$ & $24.5 \mathrm{bc}$ \\
\hline SM 20 (80\% Sand + 20\% Solarized manure) & $27.6 \mathrm{a}$ & $33.7 \mathrm{a}$ \\
\hline SM 30 (70\% Sand + 30\% Solarized manure) & $29.2 \mathrm{a}$ & $28.1 \mathrm{~b}$ \\
\hline SM 40 (60\% Sand + 40\% Solarized manure) & $20.1 \mathrm{~b}$ & $20.4 \mathrm{c}$ \\
\hline
\end{tabular}

${ }^{*}$ Result means $(\mathrm{n}=4)$, reported in $\mathrm{mm} .{ }^{* *}$ Results reported in $\mathrm{mg} \mathrm{GAE} / 100 \mathrm{~g}$ fresh weight. ${ }^{* *}$ Results reported in $\mu \mathrm{g}$ of lycopene/g dry weight. Values in columns followed by different letters in the same column are significantly different, according to the Tukey test $(\mathrm{p}<0.05)$.

\section{Benefit/cost ratio of the organic substrates}

Cost analysis (per square meter) of the organic materials used in this study for substrate formulation showed that SM20 substrate was the cheapest (\$1.59 dollars), while VC40 and VC30 had the highest costs 
(Table 7). The highest $\mathrm{B} / \mathrm{C}$ ratio for tomato production per square meter was obtained in the substrate $\mathrm{SM} 20$ (8.16), followed by $\mathrm{SM} 30>\mathrm{VC} 20>\mathrm{SM} 40>\mathrm{VC} 30$. The sand substrate had the lowest $\mathrm{B} / \mathrm{C}$ ratio (3.72).

Table 7. Benefit-cost ratio of Saladette tomato fruit produced in organic substrates formulated with sandvermicompost and sand-solarized manure

\begin{tabular}{|c|c|c|c|c|c|c|c|c|}
\hline \multirow{3}{*}{ Substrate } & \multicolumn{3}{|c|}{ Substrate costs } & \multirow{2}{*}{$\begin{array}{c}\mathrm{CTs} \\
(\mathrm{S}+\mathrm{AO}+\mathrm{CB})\end{array}$} & \multirow{2}{*}{ Yielding } & \multirow{2}{*}{ Price } & \multirow{2}{*}{$\mathrm{Bb}$} & \multirow{2}{*}{$\mathrm{Bb} / \mathrm{CT}$} \\
\hline & S & OMat & VCos & & & & & \\
\hline & \multicolumn{4}{|c|}{ - } & $(\mathrm{kg} / \mathrm{m} 2)$ & $(\$ / \mathrm{kg})$ & $(\$ / \mathrm{m} 2)$ & \\
\hline TA & 1.60 & $1.80^{*}$ & 0.52 & $3.92 \mathrm{a}$ & $18.97 \mathrm{a}$ & 0.85 & $16.12 \mathrm{~b}$ & $4.11 \mathrm{~d}$ \\
\hline VC20 & 0.62 & 1.36 & 0.52 & $2.50 \mathrm{c}$ & $13.25 \mathrm{c}$ & 1.19 & $15.76 \mathrm{~b}$ & $6.30 \mathrm{bc}$ \\
\hline VC30 & 0.55 & 2.04 & 0.52 & $3.11 \mathrm{bc}$ & $15.58 \mathrm{~b}$ & 1.19 & $18.55 \mathrm{a}$ & $5.96 \mathrm{c}$ \\
\hline VC40 & 0.47 & 2.55 & 0.52 & $3.54 \mathrm{~b}$ & $16.50 \mathrm{~b}$ & 1.19 & $19.64 \mathrm{a}$ & $5.55 \mathrm{c}$ \\
\hline ES20 & 0.62 & 0.45 & 0.52 & $1.59 \mathrm{~d}$ & $9.38 \mathrm{~d}$ & 1.19 & $11.17 \mathrm{c}$ & $7.03 \mathrm{ab}$ \\
\hline ES30 & 0.55 & 0.67 & 0.52 & $1.74 \mathrm{~d}$ & $10.49 \mathrm{~d}$ & 1.19 & $12.48 \mathrm{c}$ & $7.17 \mathrm{a}$ \\
\hline ES40 & 0.47 & 0.90 & 0.52 & $1.84 \mathrm{~d}$ & $9.52 \mathrm{~d}$ & 1.19 & $11.33 \mathrm{c}$ & $6.16 \mathrm{bc}$ \\
\hline
\end{tabular}

Values in columns followed by different letters are significantly different according to the Tukey test $(\mathrm{P} \leq 0.05)$. TA: Control with chemical fertilization; VC 20: $80 \%$ Sand + 20\% Vermicompost; VC 30: $70 \%$ Sand + 30\% Vermicompost; VC 40: 60\% Sand + 40\% Vermicompost; SM 20: 80\% Sand + 20\% Solarized manure; SM 20: $80 \%$ Sand $+20 \%$ Solarized manure; SM 20: $80 \%$ Sand + 20\% Solarized manure; S: sand; OMat: organic material; Vcos, variable cost; $\mathrm{Bb}$ : gross profit; $\mathrm{B} / \mathrm{C}=$ cost benefit ratio; ${ }^{*}$ Cost of the nutrient solution per square meter during 90 days.

\section{Discussion}

\section{Physical and chemical characteristics of the organic materials used for substrate formulation}

The physical and chemical characteristics of solarized manure and vermicompost used in this study for substrate formulation were similar to those reported by Beltrán et al. (2016), who mentioned that these organic materials provide an adequate nutrient supply for plants and contribute to improve the substrate physical properties. Micro morphological characteristics of both organic materials could be attributed to their specific preparation processing, since solarized manure is obtained by heating manure under sunlight in order to eliminate pathogens, without additional processing (Flores et al., 2015), thereby woody fragments, tissues, and angular forms were observed (Figures 1a and 1b). On the other hand, vermicompost results from organic matter (in our case of cattle manure) digestion by specific worms (Hu et al., 2004) and microorganisms during the composting stage and maturation (Lazcano et al., 2008), forming crumb structures (Tringovska and Dintcheva, 2012) (Figures 1c and 1d).

\section{Physical and chemical characteristics of the organic substrates}

Bulk density of the formulated substrates represented no risk for plant development (Acosta et al., 2014; Garbanzo and Vargas, 2014), and their electric conductivity (EC) ranged from $0.44-1.06 \mathrm{dS} / \mathrm{m}$, which could be considered below the EC levels recommended by Abad et al. (2004) for vegetable production. On the other hand, in regard of substrates $\mathrm{pH}$ Urrestarazu (2004) indicates that the optimum $\mathrm{pH}$ value for soilless crops is between 5.5 and 6.8 (moderately acid), since this is the $\mathrm{pH}$ range where nutrient assimilation occurs at maximum rate. This slight $\mathrm{pH}$ reduction could be related to the higher quantity of hydrogen ions as a result of ionization of the radicals present in vermicompost (Durán and Henríquez, 2010), whilst in solarized manure it may be due to acid production resulting from mineralization and organic matter nitrification (Azarmi et al., 2008). Regarding to organic matter (OM) content, there is not an established minimum OM content (for substrates), although the Mexican Technical Committee of National Standardization of Agricultural and Animal Products (CTNNPAP, 2007) establishes an OM content of $200-500 \mathrm{~g} / \mathrm{kg}$ vermicompost, while Urrestarazu and Salas (2004) indicates an OM content of 56.1 - 62.7\% in compost. However, as aforementioned it has not been established a minimum OM content for mineral substrates added with organic materials. 


\section{Tomato yielding}

Substrates fertilized using synthetic nutrient solutions contribute to obtain higher yielding than in organic based substrates (Díaz et al., 2014). Yielding of VC substrates and control were in the range of 12.0$15.0 \mathrm{~kg} / \mathrm{m}^{2}$. These results could be considered as acceptable since are similar to those reported in commercial operations of tomato production under protected agriculture systems, such as under shade net (De la Cruz et al., 2009; Godoy et al., 2009). This suggests that tomato production using substrates formulated with vermicompost from solarized manure can assure acceptable produce yielding.

\section{Commercial quality of tomato fruit}

Three of the most important quality parameters of tomato fruits are soluble solids content, which implies whether a tomato could be used either for processing or fresh consumption, fruit firmness, and pericarp thickness, which stands for the fruit resistance during postharvest stages such as storage and delivery (Taylor, 2002). Tomato fruits produced in vermicompost substrates of this study had an adequate firmness according to the established commercial quality standards (between 5.0 and $8.0 \mathrm{~N}$ ) (Edan et al., 1997). Besides, pericarp thickness values were higher than those reported in previous studies (Márquez et al., 2014). Tomato peeling and pericarp should be thick and firm in order to avoid produce breakage which could result in fruit juice leakage, as well as fermentation and microbial contamination during postharvest stages like shipping, storage and delivery (Gaona and Juárez, 2005). Hence, the use of organic substrates formulated with vermicompost obtained from solarized manure is a feasible alternative for production of good quality tomato fruits destined to either processing or fresh consumption. The tomato fruits produced in the vermicompost substrates had quality parameters below official commercial requirements, such as the Supreme Quality Mexican Official Norm (NOM, 1997). However, TSS content of the fruits produced with VC substrates were higher than 5 ${ }^{\circ} \mathrm{Bx}$, while those produced in SM were not. Total soluble solids content of tomato fruits destined for fresh market or industrial processing should be between 4.50 and $5.50{ }^{\circ} \mathrm{Bx}$ (Macua et al., 2006). The TSS results obtained in the current study indicate that an increase of organic materials concentration in a substrate formulation caused a slight increase in electric conductivity, which is known that affects the soluble solids content of produce. Nevertheless, the EC of the formulated substrates does not imply there was osmotic stress for the tomato plants, since EC of the formulated substrates can be considered as low $(0.43-2.50 \mathrm{dS} / \mathrm{m})$. Saline compounds contained either in substrates or soil alter water uptake in roots, thereby activating plant metabolic mechanisms that alleviate this stress through accumulation of organic solutes in fruits, diminishing osmotic potential (Goykovic and Saavedra, 2007). Thus, TSS of tomatoes in our study could result from a specific rhizosphere response, in addition to reactions of root exudates with several organic substrates compounds (Cheng, 2009).

\section{Phytochemical quality of tomato fruit}

Plant response to stressful environmental conditions triggers defensive mechanisms including antioxidants production (Winter and Davis, 2006). The tomato phenolic and lycopene content in our study were higher than those reported in other previous studies (Zapata et al., 2007; Omar et al., 2012). It has been reported that lycopene content mostly depends on the plant nutritional status, harvest time and variety (Waliszewski and Blasco, 2010). It is possible that the nutritional supply of the organic substrates was not sufficient in the early growth stages due to the mineralization and nutrient solubilization occurring at a slow rate during such stages, thereby increasing production of the carotenoid lycopene as a response to such stress factor. These results show that organic substrates formulated with vermicompost can be used for obtaining fruit tomato that meet good yielding (Grijalva et al., 2011) and commercial quality requirements (Gónzalez et al., 2004; IPGRI, 1996), as well as an adequate nutraceutical content (Sereme et al., 2016). 


\section{Benefit-cost ratio of the organic substrates}

Two of the most important features to select a substrate for protected agriculture use are optimum plant development and economic profitability for producers (Cruz et al., 2013). Preliminary results of the economic analyses state the substrate formulated using solarized manure ES20 have the highest benefits. Besides, the vermicompost substrate VC20 is a good alternative due to its positive effect over tomato yielding (Jagadeesh et al., 2018). Hence, it was determined that these two organic substrates could be used to obtain organic vegetables with a high commercial and nutraceutical quality, in addition to the economic advantages of using such substrates containing either solarized manure or vermicompost.

\section{Conclusions}

Organic substrates formulated with blends of sand and either solarized manure or vermicompost contribute to obtain tomato fruits with a high nutraceutical quality without affecting either yielding or commercial fruit quality. Besides, the use of such substrates increases the profit-cost ratio in organic tomato production under greenhouse conditions.

\section{Authors' Contributions}

Conceptualization: MAGR; Data analysis: CVV and ARG; Formal analysis, MFH, EAO and PPR; Methodology: MFH, PPR and ARG; Project administration: MAGR and JRE; Writing - original draft: MFH and EAO; Writing - review \& editing: PPR and JRE. All authors read and approved the final manuscript.

\section{Acknowledgements}

This work was supported by Tecnológico Nacional de México (TecNM). Author Elieber Antonio Ordoñez also thanks the National Council for Science and Technology of Mexico (CONACYT) for supporting his graduate studies.

\section{Conflict of Interests}

The authors declare that there are no conflicts of interest related to this article.

\section{References}

Abad M, Noguera P, Carrión C (2004). Los sustratos en los cultivos sin suelo [Substrates in soilless cultures]. In: Urrestarazu M (Ed). 3rd. ed. Tratado de cultivo sin suelo [Treaty of soilless cultures]. Ed. Mundi Prensa. Almería, Spain, pp 113-158.

Acosta DCM, Chávez GJA, Acosta PD (2014). Vermicomposta como componente de sustrato y su efecto en la raíz de cuatro especies de plantas ornamentales [Vermicompost as a substrate component and its effect over root of four ornamental plant species]. Investigación Agropecuaria 11:23-34.

Anguelova T, Warthersen J (2000). Degradation of lycopene, $\alpha$-carotene and $\beta$-carotene during lipid peroxidation. Journal of Food Science 65:71-75. https://doi.org/10.1111/j.1365-2621.2000.tb15958.x 
Atiyeh RM, Subler S, Edwards CA, Bachman G, Metzger JD, Shuster W (2000). Effects of vermicomposts and composts on plant growth in horticultural container media and soil. Pedobiologia 44:579-590. https://doi.org/10.1078/S0031-4056(04)70073-6

Azarmi R, Giglou M, Taleshmikail D (2008). Influence of vermicompost on soil chemical and physical properties in tomato (Lycopersicum esculentum) field. African Journal of Biotechnology 7:2397-2401. https://doi.org/10.5897/AJB08.378

Beltrán MFA, García HJL, Ruiz EFH, Valdez CRD, Preciado RP, Fortis HM, González ZA (2016). Efecto de sustratos orgánicos en el crecimiento de seis variedades de chile jalapeño (Capsicum annuum L.) [Effect of organic substrates over growth of six jalapeño pepper (Capsicum annuum L.) varieties]. Ecosistemas y Recursos Agropecuarios 3:143-149. http://dx.doi.org/10.19136/era.a3n7.963

Burnett SE, Mattson NS, Williams KA (2016). Substrates and fertilizers for organic container production of herbs, vegetables, and herbaceous ornamental plants grown in greenhouses in the United States. Scientia Horticulturae 208:111-119. http://dx.doi.org/10.1016/j.scienta.2016.01.001

Cheng W (2009). Rhizosphere priming effect: its functional relationships with microbial turnover, evapotranspiration, and C-N budgets. Soil Biology and Biochemistry 41:1795-1801. https://doi.org/10.1016/j.soilbio.2008.04.018

Cruz CE, Can CA, Sandoval VM, Bugarín MR, Robles BA, Juárez LP (2013). Sustratos en la horticultura [Substrates in horticulture]. Bio Ciencias 2:17-26. https://doi.org/10.15741/revbio.02.02.03

CTNNPAP (2007). Humus de lombriz (Lombricomposta), especificaciones y métodos de prueba [Vermicompost, specifications and analytical methods]. Comité Técnico de Normalización Nacional de Productos Agrícolas y Pecuarios. NMX-FF-109-SCFI-2008. D.F. México, 24 pp. http://www.economianmx.gob.mx/normas/nmx/2007/nmx-ff-109-scfi-2008.pdf

De la Cruz LE, Córdova OH, Estrada BMA, Mendoza PJD, Gómez VA, Brito MNP (2009). Rendimiento de grano de genotipos de maíz sembrados bajo tres densidades de población [Yielding of three corn kernel genotypes under three population densities]. Universidad y 25:93-98. http://www.scielo.org.mx/pdf/uc/v25n1/v25n1a7.pdf

Díaz MHA, Preciado RP, Álvarez RVP, Fortis HM, García HJL, Sánchez CHE (2014). Organic production and antioxidant capacity of cucumber fruit. Información Técnica Económica Agraria 110:335-342. https://doi.org/10.12706/itea.2014.021

Domínguez J, Lazcano CC, Gómez BM (2010). Influencia del vermicompost en el crecimiento de las plantas. Aportes para la elaboración de un concepto objetivo [Influence of vermicompost over plant growth. [Insigths for establishing an objective concept]. Acta Zoológica Mexicana 26:359-371. https://doi.org/10.21829/azm.2010.262900

Dumas Y, Dadomo M, Di Lucca G, Grolier P (2003). Effects of environmental factors and agricultural techniques on antioxidant content of tomatoes. Journal of the Science of Food Agriculture 83:369-382. https://doi.org/10.1002/jsfa.1370

Durán L, Henríquez C (2010). El vermicompost: Su efecto en algunas propiedades del suelo y la respuesta en planta [Vermicompost: Its effect over soil properties and plant response]. Agronomía Mesoamericana 21:85-93. https://doi.org/10.15517/am.v21i1.4914

Edan Y, Pasternak H, Shmulevich I, Rachmani D, Guedalia D, Grinberg S, Fallic E (1997). Color and firmness classification of fresh market tomatoes. Journal of Food Science 32:793-796. https://doi.org/10.1111/j.13652621.1997.tb15457.x

Flores SB, Segura CMA, Fortis HM, Martínez CL, Aldaco NRA, Orozco VJA (2015). Enmiendas de estiércol solarizado en la estabilidad de agregados de un aridisol cultivado de México [Ammendments of solarized manure over agreggate stability of a desert soil cultivated in Mexico]. Revista Mexicana de Ciencias Agrícolas 7:15431555. https://doi.org/10.29312/remexca.v6i7.548

Fortis HM, Preciado RP, García HJL, Navarro BA, González JA, Omaña SJM (2012). Sustratos orgánicos en la producción de chile pimiento morrón [Organic sustrates for bell pepper production]. Revista Mexicana de Ciencias Agrícolas 3:1203-1216. https://doi.org/10.29312/remexca.v3i6.1372

Frederickson J, Howell G, Hobson AM (2007). Effect of precomposting and vermicomposting on compost characteristics. European Journal of Soil Biology 43:S320-S326. https://doi.org/10.1016/j.ejsobi.2007.08.032

Gaona B, Juárez L (2005). Evaluación de variedades de jitomate (Lycopersicum esculentum Mill) bajo invernadero en Aquixtla, Puebla [Evaluation of tomato (Lycopersicum esculentum Mill) varieties produced under greenhouse 
conditions in of Aquiztla, Puebla]. Fitotecnia. Universidad Autónoma Chapingo. Estado de México, México, pp 68.

Garbanzo LG, Vargas GM (2014). Determinación fisicoquímica de diez mezclas de sustratos para producción de almácigos [Physico chemical determination of ten substrate mixtures for seedling production], Guanacaste, Costa Rica. Intersedes 15:151-168. https://doi.org/10.15517/isucr.v15i30.14874

Godoy HE, Castellanos RJZ, Alcántar GG, Sandoval VM, Muñoz RJJ (2009). Efecto del injerto y nutrición de tomate sobre rendimiento, materia seca y extracción de nutrimentos [Effect of grafting and nutrition over tomato yielding, dry matter and nutrimental content]. Terra Latinoamericana 27:1-9. http://www.scielo.org. $m x / p d f / t 1 / v 27 n 1 / v 27 n 1 a 1 . p d f$

González CA, Salas SMC, Urrestarazu GM (2004). Producción y calidad en el cultivo de tomate cherry [Cherry tomato crop production and quality]. In: Urrestarazu GM (Ed). Tratado de cultivo sin suelo [Treaty of soilless cultures]. Ed. Mundi-Prensa. Madrid, Spain, pp 547-596.

Goykovic CV, Saavedra RG (2007). Algunos efectos de la salinidad en el cultivo del tomate y prácticas agronómicas de su manejo [Some effects of salinity over tomato crop and cultural practices for product handling]. Idesia (Arica) 25:47-58. http://dx.doi.org/10.4067/S0718-34292007000300006

Grijalva CRL, Macías DR, Robles CF (2011). Comportamiento de híbridos de tomate Bola en invernadero bajo condiciones desérticas del noroeste de sonora [Behavior of beef tomato hybrids in greenhouse under desertic conditions in the northwest of Sonora]. Tropical and Subtropical Agroecosystems 14:675-682. http://www.scielo.org.mx/pdf/tsa/v14n2/v14n2a25.pdf

Hashemimajd K, Kalbasi M, Golchina A, Shariatmadari H (2004). Comparison of vermicompost and composts as potting media for growth of tomatoes. Journal of Plant Nutrition 27:1107-1123. https://doi.org/10.1081/PLN120037538

Hu Y, Sun Z, Wang D, Sun Y (2004). Analysis of antagonistic microorganisms in vermicompost. Chinese Journal of Applied and Environmental Biology 10:99-103.

IPGRI (1996). Descriptores para el tomate (Lycopersicon spp.) [Tomato descriptors (Lycopersicon spp.)] International Plant Genetic Resources Institute. Rome, Italy, pp 44.

Izquierdo SE, Hernández CC, Koss MR (1992). Preparación, administración y evaluación de proyectos agroindustriales [Preparation, management and evaluation of agriculture industry projects]. IFAIN. San José, Costa Rica, pp 247.

Jagadeesh M, Madhavi M, Siva P, Padmaja VV (2018). Effect of organic manures on benefit cost ratio of beet root Cv. Crimson Globe. International Journal of Current Microbiology and Applied Sciences 7:3612-3614. https://doi.org/10.20546/ijcmas.2018.711.413

Knekt P, Kumpulaine J, Järvine R, Rissanen H, Heliövaara M, Reunanen A, ... Aromaa A (2002). Flavonoid intake and risk of chronic diseases. The American Journal of Clinical Nutrition 76:560-568. https://doi.org/10.1093/ajcn/76.3.560

Lazcano C, Gómez BM, Domínguez J (2008). Comparison of the effectiveness of composting and vermicomposting for the biological stabilization of cattle manure. Chemosphere 72:1013-1019. https://doi.org/10.1016/j.chemosphere.2008.04.016

Macua JL, Lahoz I, Garnica I, Calvillo S, Zuñiga J, Santos A (2006). Tomate de industria: resultados de la campaña, novedades y perspectivas [Tomato for processing: Results and new perspectives]. Instituto Técnico de Gestión Agrícola. Navarra, España, pp 14.

Márquez QC, Cano RP, Moreno RA, Figueroa VU, Sánchez ChE, De la Cruz LE, Robles TV (2014). Efecto de la fertilización orgánica sobre el rendimiento y contenido nutricional de tomate saladette en invernadero [Effect of organic fertilization over yielding and nutritional content of Saladette tomato produced in greenhouses]. Información Técnica Económica Agraria 110:3-17. http://dx.doi.org/10.12706/itea.2014.001

Mayeaux M, Xu Z, King JM, Prinyawiwatkul W (2006). Effects of cooking conditions on the lycopene content in tomatoes. Journal of Food Science 71:461-464. https://doi.org/10.1111/j.1750-3841.2006.00163.x

Miles JA, Peet MM (2002). Maintaining nutrient balances in systems utilizing soluble organic fertilizers. Final Project report. Horticultural Science Department. North Carolina State University. Raleigh, NC. USA, pp 23.

Moreno RA, López AFA, Figueroa VU, Rodríguez DN, Vásquez AJ, Reyes CJL, ... Reyes VMH (2012). Tomato production in sand: vermicompost mixtures compared with sand and nutritive solution. Basic Research Journal of Agricultural Science and Reviews 1:19-26. 
Moreno RA, Meza MH, Rodríguez DN, Reyes CJL (2010). Development of muskmelon with different mixtures of vermicompost: Sand under greenhouse conditions. Journal of Plant Nutrition 33:1672-1680. $10.1080 / 01904167.2010 .496890$

NOM (1997). Productos alimenticios no industrializados para consumo humano. Hortalizas frescas. Tomate (Lycopersicun esculentum Mill). Especificaciones [Non industrialized food products for human consumption. Fresh vegetable. Tomato. (Lycopersicun esculentum Mill.). Specifications]. Normas Oficiales Mexicanas NMXFF-031-1997 [Mexican Official Norms specifications NMX-FF-031-1997]. Dirección General de Normas, pp 15. https://www.colpos.mx/bancodenormas/nmexicanas/NMX-FF-031-1998.PDF

Omar NF, Hassan SA, Yusoff UK, Abdullah NA, Wahab PE, Sinniah U (2012). Phenolics, flavonoids, antioxidant activity and cyanogenic glycosides of organic and mineral-base fertilized cassava tubers. Molecules 17:2378-2387. https://doi.org/10.3390/molecules 17032378

Perrin RK, Winkelmann DL, Moscardi ER, Anderson JR (1976). Formulación de recomendaciones a partir de Datos Agronómicos: Un manual metodológico de evaluación económica [Formulation of recommendations based on Agronomic data: A methodological manual of economic evaluation]. Report No. 27. Centro Internacional para el Mejoramiento del Maíz y Trigo. D.F. México, pp 57. https://repository.cimmyt.org/handle/10883/3816

Raffo A, La Malfa G, Fogliano V, Maiani G, Quaglia G (2006). Seasonal variations in antioxidant components of cherry tomatoes (Lycopersicon esculentum cv. Naomi F1). Journal of Food Composition and Analysis 19:11-19. https://doi.org/10.1016/j.jfca.2005.02.003

Sánchez HDJ, Fortis HM, Esparza RJR, Rodríguez OJC, De la Cruz LE, Sánchez CE, Preciado RP (2016). Empleo de vermicompost en la producción de frutos de melón y su calidad nutracéutica [Use of vermicompost for melon production and their nutraceutical quality]. Interciencia 41:213-217. http://www.redalyc.org/articulo.oa?id=33944256011

SAS (2009). JMP User Guide. Release 8. SAS Institute Inc., Cary, North Carolina, US, pp 513.

Segura-Castruita MA, Preciado RP, González CG, Frías RJE, García LG, Orozco VJA, Enríquez SM (2008). Adición de material pomáceo a sustratos de arena para incrementar la capacidad de retención de humedad [Addition of pumice residues to sand substrates in order to increase water retention capacity]. Interciencia 33:923-928. http://www.redalyc.org/articulo.oa?id=33913810

Sereme A, Dabire Ch, Koala M, Somda MK, Traore AS (2016). Influence of organic and mineral fertilizers on the antioxidants and total phenolic compounds level in tomato (Solanum lycopersicum) var. Mongal F1. Journal of Experimental Biology and Agricultural Sciences 4:414-420. http://dx.doi.org/10.18006/2016.4(Issue6).631.63

Singleton VL, Orthofer R, Lamuela RRM (1999). Analysis of total phenols and other oxidation substrates and antioxidants by means of Folin-Ciocalteu reagent. Methods Enzymology 299:152-178. https://doi.org/10.1016/s0076-6879(99)99017-1

Steiner AA (1984). The universal nutrient solution. In: Proceedings of the sixth international congress on soilless culture. International Society for Soilless Culture. Lunteren, Netherlands pp 633-649.

Suvo TP, Biswas H, Jewel MH, Islam MD, Seragul K, Shafiqul I (2017). Impact of substrate on soilless tomato cultivation. International Journal of Agricultural Research, Innovation and Technology 6:82-86. https://doi.org/10.3329/ijarit.v6i2.31710

Taylor AJ (2002). Release and transport of flavours in vivo: Physicochemical, physiological, and perceptual considerations. Comprehensive Reviews in Food Science and Food Safety 1:45-57. https://doi.org/10.1111/j.15414337.2002.tb00006.x

Tringovska I, Dintcheva T (2012). Vermicompost as substrate amendment for tomato transplant production. Sustainable Agriculture Research 1:115-122. https://doi.org/10.5539/sar.v1n2p115

Urrestarazu M (2004). Tratado de cultivos sin suelo [Treaty of soilless crops]. 3rd edition. Mundi-Prensa. Madrid, Spain, pp 91.

Urrestarazu M, Salas M (2004). Cultivo en sustratos alternativos [Crops in alternative substrates]. In: Urrerarazu M (Ed). 3rd edition. Tratado de cultivos sin suelo [Treaty of soilless crops]. Mundi-Prensa. Madrid, Spain, pp 669-690.

USDA (2014). Keys to soil taxonomy. Soil Survey Staff. 12th Ed.: United States Department of Agriculture - Natural Resources Conservation Service. Washington, D.C. U.S., pp 410. https://www.nrcs.usda.gov/wps/portal/nrcs/detail/soils/survey/class/taxonomy/?cid=nrcs142p2_053580

Vázquez Vázquez C, Salazar Sosa E, Fortis Hernández M, Reyes Oliva MI, Zúñiga Tarango R, González JA (2010). Uso de cubiertas plásticas para solarización de estiércol bovino [Use of plastic films for solarization of bovine cattle 
Fortis Hernandez M et al. (2021). Not Bot Horti Agrobo 49(1):11999

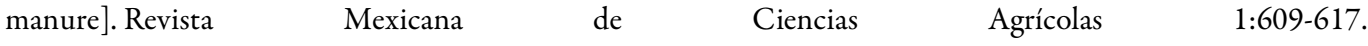
http://www.scielo.org.mx/pdf/remexca/v1n4/v1n4a13.pdf

Vázquez VC, García HJL, Salazar SE, López MJD, Valdez CRD, Orona CI, ... Preciado RP (2011). Aplicación de estiércol solarizado al suelo y la producción de chile jalapeño (Capsicum annuum L.) [Soil-applied solarized manure in the production of jalapeño pepper (Capsicum annuum L.]. Revista Chapingo Serie Horticultura 17:69-74. http://www.scielo.org.mx/pdf/rcsh/v17nspe1/v17nspe1a11.pdf

Waliszewski KN, Blasco G (2010). Propiedades nutracéuticas del licopeno [Nutraceutical properties of lycopene]. Salud Pública Mexicana 52:254-265. https://scielosp.org/pdf/spm/2010.v52n3/254-265/es

Wang Y, Wu WH (2010). Plant sensing and signalling in response to $\mathrm{K}^{+}$deficiency. Molecular Plant 3:280-287. https://doi.org/10.1093/mp/ssq006

Winter CK, Davis SF (2006). Organic foods. Journal of Food Science 71:17-124. https://doi.org/10.1111/j.1750 3841.2006.00196.x

Yeager TH, Fare D, Lea-Cox J, Ruter J, Bilderback TE, Gilliam CH, ... Tilt KM (2007). Best management practices: Guide for producing container-grown plants. 2nd ed. Southern Nurserymen's Association, Maretta, GA. U.S. pp 4-10. https://mda.maryland.gov/resource_conservation/Documents/consultant_information/1997\%20IIE\%20p1-7\%20s0.pdf

Zapata LM, Gerard L, Davies C, Schvab MC (2007). Estudio de los componentes antioxidantes y actividad antioxidante en tomates [Study of the antioxidant components and activity of tomato fruits]. Ciencia, Docencia y Tecnología 35:173-193. http://www.redalyc.org/articulo.oa?id=14503507

OPEN ACCESS

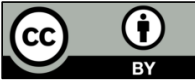

The journal offers free, immediate, and unrestricted access to peer-reviewed research and scholarly work. Users are allowed to read, download, copy, distribute, print, search, or link to the full texts of the articles, or use them for any other lawful purpose, without asking prior permission from the publisher or the author.

License - Articles published in Notulae Botanicae Horti Agrobotanici Cluj-Napoca are Open-Access, distributed under the terms and conditions of the Creative Commons Attribution (CC BY 4.0) License.

(c) Articles by the authors; UASVM, Cluj-Napoca, Romania. The journal allows the author(s) to hold the copyright/to retain publishing rights without restriction. 